\title{
Dr. J.G. Geelkerken as kontroversis (1920-1926)
}

G.L. Kruger

Departement Bybelkunde

Vaaldriehoekkampus van die $\mathrm{PU}$ vir $\mathrm{CHO}$

VANDERBIJLPARK

\begin{abstract}
Dr. Johames (jerardus (jec/kerken (13 June 18793 Februan 1960) got molved in a controversy with the (iereformeerde Kerken m the Netherlands derring the period 192+-1926. The issue at stake was the historical reality of (jenesis 2 and 3.

Dhe to the controversial character of Dr. (jeelkerken. 1ension had been prevalent in his congregation even before the controversy. This tension added to the controversy. resulling in a form of a personal confluct benween 1)r. (jeelkerken and the church. ('onsequently, this conflict led to the dismissal of Dr. (ieelkerken and the resuliam schism of the church.

This artucle show's how the course of the conroversy was affected by (jeelkerken's proneness to controversy and how the form of the final deciston of the Simod of Assen m 1926 was determined by his negative and evasive attumde. This dimension of the debate is important in understanding the critique provoked by the deciston of Assen which eventually led to its withdrawal by the Synod of Amsterdam in 1967.
\end{abstract}

\section{Inleiding}

Dr. J.G. Geelkerken het sy bekendheid in kerklike kringe verwerf deur sy betrokkenheid by die kontroverse met die Gereformeerde Kerke in Nederland (1924-1926). Hierdie geskil het oor die historiese werklikleid van die sogenaamde vier besonderhede in Genesis 3 en 4 gehandel, te wete die twee bome in die tuin van Eden, die slang en die vermelding dat die slang gepraat het Die twispunt was dus van Skrifbeskoulike aard. Die vraag na die beskoung van die Skrif, spesifick die opvatting oor geskiedenisbeskrywing in die Skrif en die aard van die daaruit voortvloeiende gesag van die Skrif, is steeds van aktuele belang in die gerefonnecrde kerkfamilic.

Aangesien sy persoonlikheid en houding - meer as sy sienswyse oor Genesis 2 en 3 (wat hy in elk geval nooit gedurende die kontroverse uitdruklik onder woorde gebring het nie) - 'n besondere invloed op die ongelukkige kerkregtelike verloop 
van die kontroverse gehad het, is dit belangrik om ter wille van ' $n$ beter begrip van die besluit van die Sinode van Assen 1926, op die persoon, Geelkerken, en sy manier van optrede te fokus. Dit sal blyk dat sy kontroversistiese persoonlikheid meegewerk het tot die abnormale kerkregtelike verloop én omstandighede waaronder die besluit geneem is. Dit is juis dié abnonnaliteite wat tot felle kritiek gelei teen die sogenaamde 'gees van Assen' ('n uitdrukking waarmee die 'jongeren'-beweging hulle gevoel van afkeur teen die uitspraak van Assen en die wyse van kerkregtelike hantering te kenne wou gee) en die uiteindelike tersydestelling van die Assenuitspraak.

\section{Dr. Geelkerken in die periode voor sy bediening}

Johannes Gerardus Geelkerken is op 13 Junie 1879 te Alkmaar, Nederland gebore (Buskes, 1961:52). Sy vader was eers aan die Hervonnde Kerk van Nederland verbonde maar nadat hy in 1887 in botsing met die kerk gekom het, het hy lidmaat van die Gerefonmeerde Kerk Utrecht geword. Daar het hy tot met sy dood in 1891 as ouderling gedien (Buskes, 1961). Sy moeder, aanvanklik 'n vrysinnige, het 'n oortuigde gereformeerde geword. Hoewel die jonge Jan, soos hy genoem is, met die afsterwe van sy vader maar twaalf jaar oud was, was die godsdienstige opvoeding wat hy van laasgenoemde ontvang het van só ' $n$ aard dat dit 'n blywende indruk op hom gemaak het (Buskes, 1961). Volgens 'n ontboeseming in sy intreepreek te Amsterdam-Suid (GKN, 1926(b):98) het hy reeds as jong seun die begeerte uitgespreek oin "... het licht des evangelies te ontsteken ...".

Geelkerken het sy laerskoolonderrig te Utrecht aan 'n Christelike laerskool van die Hervormde Kerk by die Domplein ontvang. Ter wille van sy hoërskoolopleiding het sy familie na Amsterdam verhuis waar hy onderrig aan die Gereformeerde Gimnasium by die Keizersgracht ontvang het. Na voltooiing van sy skoolloopbaan moes hy kies tussen 'n 'wetenskaplike' en 'n kerklike loopbaan. Hy het laasgenoemde gekies. In 1899 het hy by die Vrije Universiteit van Amsterdam as teologiese student ingeskryf. Hier het hy van sowel Abraham Kuyper as Herman Bavinck groot invloed ondergaan. Mettertyd het hy en die 'jongeren' hulle egter aan die kant van Bavinck geskaar (Geelhoed, 1950:19). Die 'jongeren' was 'n stroom van vernuwende denke in die Gereformeerde Kerke in Nederland wat hulle invloed sedert die Sinode van Leeuwarden in 1920 tot met die kerklike geskil van die Sinode van Assen in 1926 in 'n besondere mate laat geld het. Bavinck is beskou as die vader van die 'jongeren' (Meuleman, 1956:489).

Op 11 Oktober 1909 doktoreer hy met 'n proefskrif getiteld "De empirische godsdienstpsychologie". In 'n kompetisie vall die Stedelijke Universiteit het Geelkerken se proefskrif die onderskeiding van 'n eervolle vermelding behaal. Die prys van 'n goue medalje het hom egter ontwyk op grond van die kritiek dat hy ten onregte aan die godsdienstige bewussyn wetenskaplike kenniswaarde toegeken het (Buskes, 1961:53). Afgesien van genoemde kritiek, lê dr. Geelkerken groot weten- 
skaplike vaardigheid aan die dag en behaal hy 'n baie hoë peil van wetenskaplikheid (Kruger, 1991:24). Sy waardering vir die empiriese metode is duidelik en hy wil dankbaar daarvan gebruik maak (Geelkerken, 1909:280, 281), dog met die gevaar van die positiwisme reken hy deeglik af (Kruger, 1991:367, 390-395).

Die proefskrif van dr. Geelkerken kan as 'n vroeë aanloop tot die gedagtes van die 'jongeren' gesien word (Kruger, 1991:24, 25). Die rol wat die sielkunde by die 'jongeren' se interpretasie van die inspirasieleer speel, moet teen die agtergrond van dié proefskrif gesien word; so ook dr. Geelkerken se gedagte oor die vryheid van eksegese. Laasgenoemde hang saam met sy opvatting oor die vryheid van die persoonlikheid (Kruger, 1991).

Só oorwerk was dr. Geelkerken na sy studie dat hy vir twee jaar moes rus. Op 5 Februarie 1911 word hy deur ds. K. Fenhhout, latere voorsitter van die bekende Sinode van Assen, in die Gereforncerde Kerk van Epe as predikant bevestig. Vier jaar later, op $30 \mathrm{Mei}$ 1915, is hy in die Gereformeerde Kerk van Amsterdam-Suid bevestig waar hy tot met sy afsetting op 17 Maart 1926 gedien het.

\section{Dr. Geclkerken se bedieningstyd te Amsterdam-Suid}

Gedurende dr. Geelkerken se bediening te Amsterdam-Suid het die kontroverse sy ontstaan én afloop gehad. Ter wille van 'n goeie begrip van die kontroverse is dit belangrik om die agtergrond waarteen die heersende spanning en partyskappe in die kerk sy ontstaan gehad het, nader toe te lig. Van die belangrikste bronne wat oor die voorspel tot die kontroverse beskikbaar is, is dié van $\mathrm{K}$. van den Berg en H. Marinus, onderskeidelik 'n medestander en teenstander van dr. Geelkerken.

Voór dr. Geelkerken se bevestiging in 1915 was daar reeds hewige spanning in die kerk van Amsterdam-Suid oor die kwessie van kerkbou (Van den Berg, 1925: $3,4)$. 'n Deel van die kerkraad en gemeente was baie ontevrede oor die feit dat daar, in plaas van één groot kerk, 'n tweede kerk naas die bestaande kerk gebou is. In dieselfde jaar het daar verdere spanning ontstaan omdat dr. Geelkerken nie die éérste nie maar wel die twééde beroep as inedeleraar na Amsterdam-Suid opgevolg het (Marinus, 1925:25). Veral die persone wat verkieslik 'n predikant wou beroep wat in Kampen gestudeer het, was ongelukkig oor die feit dat dr. Geelkerken vir 'n tweede keer beroep is. 'n Sekere broeder De Free was van mening dat 'n predikant met karakter nie 'n tweede beroep sou opgevolg het nie (Marinus, 1925).

Volgens Van den Berg (1925:4) het die spanning in die gemeente mettentyd tot partyskappe gegroei waarin die twee predikante teenoor mekaar te staan gekom het. Dr. Geelkerken het die grootste aanhang geniet. Dit het jaloesie by en verdagmaking (Van den Berg, 1925:6) deur "een clubje malcontenten" (Van den Berg, 1925:9) tot gevolg gehad Laasgenoemde het byvoorbeeld hulle misnoeè oor sekere liturgiese veranderings gedeinonstreer "... door het stelselmatig blijven 
zitten onder het zingen van het psalmvers, dat op de voorlezing van de wet volgde ..." (Van den Berg, 1925:10).

Dr. Geelkerken het hom heelhartig aan die bediening gewy (Buskes, 1961:53, 54). Benewens sy taak as verkondiger van die Woord, kategeet en herder, het hy hom ook aan die werk van sending en evangelisasie gewy en hom vir die ekumeniese beweging beywer. Vir laasgenoemde het hy sedert sy studentejare 'n besondere liefde gehad wat uit sy verbintenis met die Nederlandse Christen Studente Vereniging (N.C.S.V.) voortgespruit het. Sy ekumeniese ywer het tot samewerking met die Lutherse predikant, dr. Stegenga, en die Hervonnde predikant, dr. De Vrijer, op die gebied van evangelisasie gelei (Buskes, 1961:54). Hierdie verbintenis het daartoe aanleiding gegee dat prof. H.H. Kuyper in De Heraut (1925-11-08) dr. Geelkerken se naam aan die vrysinnige Skrifbeskouings van bogenoemde twee persone gekoppel het. Dit het ook daartoe bygedra dat die Sinode van Assen hom daarvan verdink het dat hy onder die invloed van etiese beskouings was.

\section{Die Sinode van Leeuwarden}

Dr. Geelkerken het die Gereformeerde Kerke in Nederland se verhouding tot die wêreld as te eng en hulle beskouing van die Skrif as te fundamentalisties gesien en kon dit nie met sy eie sin vir ruimheid, openheid en onafhanklikheid versoen nie (Buskes, 1961:53, 54). Hierdie spanning met die kerk het dr. Geelkerken in die jaar 1920 op vier punte met die sinode laat bots.

\subsection{Die Netelenbossaak}

In hierdie saak het dr. Geelkerken en ds. J Brussaard eerstens verskil oor die wyse waarop klassis Middelburg die saak van ds. J.B. Netelenbos kerkregtelik gehanteer het. Tweedens kon hulle hulle nie in alle opsigte versoen met die gronde waarop die sinode ds. Netelenbos veroordeel het nie. Hoewel hulle self op baie punte van ds. Netelenbos verskil het (GKN, 1920:104), het hulle veral van die sinode se beoordeling van ds. Netelenbos se teenargument verskil. Ds. Netelenbos is deur klassis Middelburg afgesit op grond van sy bewering dat “... de laatste en diepste grond van ons geloof niet in de Schrift kan liggen, maar alleen kan gevonden worden in den mensch zelf, in het religieuse wedergeboren subject .." (GKN, 1920:111). Die sinode was dit met klassis Middelburg eens dat so 'n siening in stryd was met die gereformeerde siening dat die Heilige Gees nie die objektiewe goddelike gesag van die Skrif in die mens se hart skep nie maar slegs tot erkenning daarvan lei (GKN, 1920).

Volgens Geelkerken en Brussaard het die sinode ds. Netelenbos se teenargument nie deeglik in ag geneem nie. Ds. Netelenbos het beweer dat sy veroordeling berus op 'n gebrek aan onderskeiding tussen die “... zijns-grond en den ken-grond van den goddelijke autoriteit der Heilige Sclırift ..." (GKN, 1920:104). Ds. Nete- 
lenbos het gemeen dat sy siening, as gevolg van hierdie gebrek aan onderskeiding, verkeerdelik in etiese sin opgeneem is asof hy beweer het dat die goddelike gesag van die Skrif afhanklik gestel word van die werking van die Heilige Gees in die mens se hart. Volgens Netelenbos moes sy bewering so verstaan word dat die openbaring wel onafhanklik van die mens geskied (die synsgrond) maar deur die Gees in die mens se hart gewerk word (die kengrond) om sodoende die grond van die geloof te vorn. Netelenbos verduidelik laasgenoemde soos volg: “... voor mij [bestaat er - G.L.K.] geen openbaring, geen ingeving ..., als Hij er mijn oog niet voor open ..." (GKN, 1920:103). Die siening wat in laasgenoemde aanhaling weerspieël word, is nou verwant aan Geelkerken (1909:361) se beskouing van religie as die afhanklikheidsbew'ussyn van die vrye persoonlikheid teenoor 'n absolute Persoonlikheid. Geelkerken se empatie met ds. Netelenbos is dus te begryp.

\subsection{Die getuienis van Ieeuwarden}

In die tweede plek het dr. Geelkerken heftig gereageer op die sogenaamde getuienis wat die sinode laat uitgaan het teen dwalinge wat vir die kerk 'n gevaar ingehou het. Sy reaksie vloei voort uit die feit dat die beskrywingspunt insake die getuienis, klaarblyklik as teenwig teen die beskrywingspunt van Amsterdam-Suid oor die hersiening van die belydenis bedoel was. Voorts is die amendement wat ouderling Van Commenée van Amsterdam-Suid (GKN, 1926(b):128) op die geformuleerde getuienis ingedien het - en wat ook aanvaar is (GKN, 1920:27) weggelaat in die finale redaksie wat an die kerkrade gestuur is (Monnik, 1920: 15). In teenstelling tot die waarskuwende strekking van die getuienis, was die amendement van 'n aansporende aard. Die amendement het veral 'n aansporing tot evangelisasie bevat.

Oor die weglating van die amendement was dr. Geelkerken só ontsteld dat hy hom, na die voorlesing van die getuienis aan die gemeente, in 'n preek daarian gedistansieer het. In die preek het hy gekla oor die kerk wat vir 'n wêreld, wat hom in sy nood tot die kerk gewend het, geen oog, oor en hart geliad het nie (Monnik, 1920:6). Die veroordeling van dr. Geelkerken se gepubliseerde preek, "Machteloosheid en krachtsontplooiing der kerk", deur middel van die teenpublikasie "Kerk en wêreld" van prof. J. Ridderbos, het direk tot poolvorming in die Gerefonneerde Kerke in Nederland gelei - 'n ontwikkeling wat grootliks tot die spanningsvolle aard van die latere kontroverse bygedra het

\section{3 l ceuwarden en die N.C.S.I.}

Dr. Geelkerken se verbintenis met die N.C.S.V. het 'n wrywingspunt tussen hom en die kerk geskep (Ridderbos, 1920:9). Net soos dr. M. van Rhijn (1920:130; Eene Gerefonneerde, 1921:189) van die Hervonnde Kerk in Nederland, het ook dr. Geelkerken die tekortkomnge van die kerk as 'n verskoning vir die bestaansreg van die N.C.S.V. gesien (Ridderbos, 1920:9). Dr. Geelkerken se ver- 
bintenis met die N.C.S.V. dui daarop dat hy hom ten opsigte van die Gereformeerde Kerke in Nederland in 'n systroom bevind het. Hierdie situasie het die potensiaal van spanning en selfs botsing met die kerk ingehou.

Die botsing het dan ook gekom toe die Sinode van Leeuwarden 'n waarskuwing teen die 'besmettingsgevaar' van die N.C.S.V. laat hoor het (Wielenga, 1920(a): 72). Die aktiwiteite van die N.C.S.V. het vir die sinode die gevaar ingelıu dat dit die kerk juis van sy funksie kon beroof. Ridderbos (1920:9) is van mening dat dr. Geelkerken se teleurstelling oor dié besluit deels tot sy heftige reaksie teen die getuienis van die sinode bygedra het.

\subsection{Die konflik oor gesange}

In die vierde plek is daar nie aan die versoek van Amsterdan-Suid gevolg gegee om artikel 69 van die Kerkorde só te wysig dat die "Eenige Gesange" met Gereformeerde Kerkliedere (gesange) uitgebrei kon word nie. Dié versoek het juis 'n ekumeniese gerigtheid gehad, naamlik on Gereformeerde kerkgemeenskappe en groepe buite die Nederlandse Gereformeerde Kerke te akkommodeer (GKN, 1920:13, 17).

\section{Die gevolge van Leeuwarden}

Volgens Van den Berg (1925:4) het dr. Geelkerken se bemoeienis met die saak van ds. Netelenbos hom baie vyande besorg - dit is as 'n vereenselwiging met die Skrifbeskouing van ds. Netelenbos vertolk. Ook die preek van dr. Geelkerken teen die sinodale getuienis het hewige debatte in die Kerkraad van AmsterdamSuid ontlok en die spanning tussen dr. Geelkerken en sy medeleraar, ds. A van Dijken, vererger (Van den Berg, 1925:5). In die volgende insident (a.w:5), voortspruitend uit die gesangekwessie, het hierdie spaming selfs op openlike konfrontasie tussen die twee predikante uitgeloop (Van den Berg, 1925:5, 6).

\subsection{Die gesangekwessie}

Ds. Van Dijken, redakteur van die Overloomsche Kerkbode (gemeenteblad van Amsterdam-Suid) is versoek on 'n resensie te skryf oor 'n bundeltjie kerkliedere wat deur die "Kring van belangstełlenden in de verrijking van ons kerkgesang" in 1922 uitgegee is. Dr. Geelkerken was die voorsitter van laasgenoemde vereniging. In plaas van 'n blote resensie, het ds. Van Dijken vier artikels oor die gesangekwessie geskryf en wel op só 'n wyse dat dit " ... den temperamentvolle Dr. Geelkerken, naar de pen deed grijpen en deze bestreed, op zeer scherpen toon ..." (Van den Berg, 1925:5). So hewig het die polemiek geword dat die klassis moes ingryp. Hoewel die klassis 'n formele versoening tussen die twee predikante bewerkstellig het, het die polemiek 'n pernanente kloof in die gemeente veroorsaak 
'n Resultaat van die stryd was dat ds. Van Dijken deur dr. Geelkerken as redakteur van die ()vertoomsche Kerkhode vervang is. Van den Berg (1925:6) beweer dat die redakteurskap valı dr. Geelkerken deur sy teëstanders as 'n geleentheid aangegryp is om hom te monitor en sodoende 'n saak teen hom op te bou. Op die Sinode van Assen was daar dan ook klagtes oor artikels wat dr. Geelkerken in die (Jvertoomsche Kerkbode geskryf het (GKN, 1926(b):58, 59)

Die oorsaak val die sensitiwiteit oor gesange kan moontlik toegeskryf word aan sekere skerp uitlatings wat dr. Geelkerken in 'n preek oor gesange gemaak het. Marimus (1925:27) beweer dat dr. Geelkerken in 'n preek sou gesê het: "In de gevangenis heeft men ver meer vrijheid dan gij gemeente, want daar mogen gezangen worden gezongen ..." Van den Brink (1925:43) beweer dat Geelkerken se opinie oor gesange hom die gramskap van "... een kringetje mannen, die ... de leiding van zaken in handen hebben en de lakens uitdelen ..." op die hals gehaal het. Volgens Van den Brink was hierdie gramskap teen dr. Geelkerken 'n belangrike oorsaak dat die kerklike prosedure teen dr. Geelkerken in 'n persoonlike vete ontaard het. Die kern van die klag teen dr. Geelkerken oor die gesange was: “... het pleiten voor het nieuwtestamentische kerklied op een wijze die aanstoot geeft en het aanzien der synode ondemijnt ..." (GKN, 1926(b):58).

As gevolg van 'n kritiese resensie wat ds. J.E. Vonkenberg in die Gereformeerde Jongelingsblad oor die bundeltjie gesange geskryf het, het die gesangekwessie 'n invloed op die besondere verloop van die kerklike geding gehad. Oor dié resensie was dr. Geelkerken baie gegrief. Hy het dit as vol vooroordeel teenoor hom beskou. Hierdie grief het later aanleiding gegee tot dr. Geelkerken se verset teen die kommissie wat die klassis aangaande dr. Geelkerken moes adviseer. Dr. Geelkerken se beskuldiging dat die kommissie teenoor hom bevooroordeeld was, was as gevolg van ds. Vonkenberg se teenwoordigheid op die kommissie (Geelkerken, 1925(d):21, 22). Sy weerspannige houding jeens dic kerklike hantering van die kontroverse het grootliks uit die grief voortgespruit.

\section{Sy karaktereienskappe}

Dit is belangrik om op hierdic stadiun in te gaan op sekere karaktereienskappe van dr. Geclkerken, wat tot konfliksituasies bygedra het. Van den Berg (1925:5) het byvoorbeeld vroeèr in dic artikel verwys na ".. den temperamentvolle Dr. Geelkerken ...". Sy laterc kollega en medestryder, dr J.J. Buskes (1961:55, 56), mak die volgende uitlating ten opsigte van dr. Geelkerken:

Veel minder dan de meesten wist hy zijn moeilijke eigenschappen te verbergen of te camoufleren ... zijn medestanders, die hem in de steek lieten, hebben zich vaak beroepen op zijn karakterfouten, alsof het om die karakterfouten ging... 
Die klaer in die saak teen dr. Geelkerken, broeder H. Marinus (1925:27), skryf: "Bediening des Woords ik betuig, dat ik ze uit Dr. Geelkerken's mond meermalen met genot heb gehoord, al heeft zijn superieuriteit (kursivering van my, G.L.K.) mij nooit een bewonderaar van hem kumnen maken." Ondersteuners van dr. Geelkerken het van soortgelyke eienskappe melding gemaak. So het ds. Sillevis Smitt na sy "styfhoofdigheid" (GKN, 1925:61, 62) en dr. Van den Brink $(1925: 44)$ na sy "hoogheidsgevoel" verwys.

\section{Die milieu waaruit die twispunt ontstaan het}

Uit bogenoemde is dit egter duidelik genoeg dat daar reeds vóór die aanhangigmaking van die klag teen dr. Geelkerken se preek 'n konfliksituasie in die kerk van Amsterdam-Suid geheers het. Aan die cen kant was daar 'n groep ontevredenes teenoor wie dr. Geelkerken allermins 'n versoenende houding openbaar het. Aan die ander kant het die kerkraad rondom sy persoon geledere gesluit. ' $n$ Bevinding van die regskommissie van die Sinode van Assen was dat die kerkraad totaal onder die invloed van dr. Geelkerken verkeer het en alle klagtes wat teen hom ingebring is eenvoudig "... in den doofpot stopte ..." (GKN, 1926(b):70). Hulle ondersoek na die 'psigologiese' faktore wat tot die Geelkerken-kwessie aanleiding gegee het, het tot die bevinding gelei dat die klag van II. Marinus nie as 'n geissoleerde geval gesien moet word nie. Hierdie klag was maar slegs één uiting van ' $n$ hele gees van ontevredenheid wat onder ' $n$ deel van die gemeente geheers het. Die regskommissie was van oordeel dat die hooghartige houding van dr. Geelkerken jeens Marimus aan hierdie ontevredenheid toe te skryf is. Dr Geelkerken sou Marinus naamlik beskou het as “... een malcontent wiens optreden ... ten nouste samenhing met de actie van een kleine maar roerige groep van gemeenteleden tegen de predikant gericht, die allenminst steun moclit ontvangen ..." (GKN, 1926(b):70, 71). Dr. Geelkerken (1926(b):9, voetnoot 3) verraai self in een van sy brosjures dié houding van hooghartigheid tecnoor H. Marinus.

\section{Die klag teen dr. Geelkerken}

Op 26 Maart 1924 het H. Marinus, lidmaat van Amsterdam-Suid, hom gewend tot die kerkraad met 'n beswaar oor dr. Geelkerken se preek oor Sondag 3 van die Heidelbergse Kategismus. Die preek is op Sondagaand 23 Maart gelewer Marinus se klag het gehandel oor uitlatings van dr. Geelkerken ten opsigte van die vier besonderhede van Genesis 2 en 3, te wete die twee bome in die tuin van Eden, die slang en die vennelding dat die slang gepraat het Volgens Marinus kom die uitlatings daarop neer dat daar 'n ander moontlikheid as die letterhke opvatting van die vier besonderhede bestaan.

Hoewel dr. Geelkerken nooit die historiese werklikheid van die sogenaamde vier besonderhede per se ontken het nie, het dit tog later (GKN, 1926(b):27) geblyk dat hy die feit van die sondeval nie afhanklik van die historiese werklikheid van 
die vier besonderhede wou stel nie. Dit, en sy latere motivering vir die bepaalde uitlatings in sy preek, dui op die feit dat dr. Geelkerken sekere oortuigings met die 'jongeren' gedeel het. Die betrokke verwysings in sy preek het, volgens ' $n$ opmerking van dr. Geelkerken (1926(a):45, voetnoot 1), aanleiding gevind in die feit dat 'n deel van sy gemeente probleme met Genesis 2 en 3 ondervind het. Hy was daaroor besorg dat hulle in hulle geloof geskok sou raak as gevolg van die feit van die sondeval. Dit wou hy deur middel van die verwysings in sy preek verhoed.

Sy teikengroep dui op die sogenaande 'jongeren' wat deur die konserwatiewes of 'ouderen' as "problemensjouwers" (Wielenga, 1921:173; Kruger, 1991:46) bestempel is - juis vanwee hulle beheptheid met allerlei vraagstukke. Hy behoort dit dus te wagte gewees het dat 'n reaksie van die kant van die 'ouderen' oor sy eensydige besorgdheid oor die probleembehepte 'jongeren' nie sou uitbly nie. Die rede waarom die Sinode van Assen ontken het dat "... een of ander eksegese van Genesis 2 en 3 ..." (GKN, 1926(b):126) in sy uitspraak in geding was, blyk uit nadere ondersoek (Kruger, 1991:40) daarin geleè te wees dat die sinode nie 'n “... vraagstuk van eksegese ..." (GKN, 1926(c):48) daarvan wou maak nie. Dit wil dus voorkom asof dr. Geelkerken se preek 'n kontroversistiese opset gehad het vanweë die nadruk op 'n probleem.

\section{Die hantering van die klag}

Uit die staanspoor het die kontroverse, wat uit dié klag voortgespruit het, vasgeval in die kwessie van die sogenaamde 'tweěrlei lesing ...' (GKN, 1925:6). Dit behels die probleem dat Marinus se weergawe van die preek verskil het van dié van $\mathrm{dr}$. Geelkerken. Die probleem is verder gekompliseer deur die feit dat $\mathrm{dr}$. Geelkerken sy preek vry van 'n skets af voorgedra het en eers in die week ná hy van die klag teen hom verneem het, 'n weergawe van sy preek op skrif gestel het (Geelkerken, 1926(b):37). Vir dié probleem kon daar nie 'n oplossing gevind word nie. Aan die een kant het Marinus hardnekkig aan dit wat hy gehoor het vasgehou en wou hy die geskrewe weergawe van dr. Geelkerken nie aanvaar nie (Marinus, 1925:23). Aan die ander kant het dr Geelkerken, wat aanvanklik sy weergawe as 'n saaklike weergawe (dus nie 'n woordelikse nie) aangebied het (GKN, 1925:5), mettertyd wel op die status van 'n woordelikse weergawe aanspraak gemaak (GKN, 1925:26, 27).

Die gevolg hiervan was dat Klassis Amsterdam, ten einde raad, dr. Geelkerken versoek het om 'n verklaring af te lê waarin hy die historisiteit van Genesis 3 moes bevestig en verklaar dat " ... hetgeen br. Marinus heeft gemeend in zijn prediking van hem te hebben gehoord door hem nóch is bedoeld, nóch is gezegd ..." (GKN, 1925:15). Dr Geelkerken (GKN, 1925:15) het egter geweier om dié verklaring af te lê en het geèis dat Marinus se klag eerder as ongegrond beskou moes word (Marinus, 1925:7). Dié eis het ooreengestem met die vroeëre be- 
vinding van sy kerkraad (GKN, 1926(b):65). In die weiering van dr. Geelkerken het die klassis die rede gevind om oor te gaan tot die versoek dat dr. Geelkerken 'n nadere verklaring moes aflê kragtens die ondertekeningsfonmulier (GKN, 1925: 15). Gepaard hiermee het die klassis die fokus verskuif van Marinus se klag na die skriftelike weergawe van dr. Geelkerken se preek (GKN, 1925:18, 19).

\section{Die reaksie van dr. Geelkerken}

In die eerste plek het dr. Geelkerken homself verontreg gevoel oor die inwerkingstelling van die ondertekeningsfonmulier. Wat hom betref, het dit hom onder verdenking geplaas sonder dat daar 'n saak teen hom uitgemaak is (Geelkerken, 1925(b):3, 4). Verder het hy die opskorting van Marinus se klag tot tyd en wyl die klassis se ondervraging afgelıandel sou wees, asook die daaropvolgende ondervraging, as ' $n$ aksie beskou wat die klassis namens Marinus ondeneem het (GKN, 1925:13, 14; Geelkerken, 1926(b):17). Hy het dit as 'n aksie ervaar wat teen sy persoon gemik was (Geelkerken, 1926(a):43). Ongelukkig kan die swak geformuleerde besluit van die klassis op 22 April 1925 inderdaad aanleiding tot so 'n vertolking gee (Kruger, 1991:120).

Van toe af sou die klassis dit aan die lyf begin voel wat dr. Geelkerken daannee bedoel het toe hy gewaarsku het dat as 'n ondervraging teen hom ingestel sou word hy die klassis sukses daarmee toewens “... maar plezier zullen zij er niet van beleven ..." (Geelkerken, 1926(b):14). Volgens Knoppers (1926:74), skriba van die sinode, sou dr. Geelkerken gesê het: "Men zal er lol van hebben." Die klassisvergadering van I April 1925 was die laaste vergadering wat dr. Geelkerken persoonlik bygewoon het. Sy optrede is daana gekenmerk deur ontwyking, vertraging en minagting van die klassis. Sy antwoorde op die vrae wat die klassis aan hom gestel het, was deurgaans vaag en ontwykend (GKN, 1925:64, 65).

Hierdie houding het aanleiding gegee tor 'n reeks van nege vrugtelose klassisvergaderings. Deurentyd is sy antwoorde ná die keerdatum ingedien en soms só laat dat die kommissie nie hulle verslag betyds gereed kon kry nie. Die klassis moes dan verdaag om maar weer op 'n volgende keer te vergader. By twee geleenthede was daar geen skriftelike antwoord van hom nie omdat hy onder andere op reis gegaan het sonder om die klassis vooraf daarvan in kennis te stel. As gevolg van dr. Geelkerken se ontwykende houding en kontroversistiese optrede deur middel van sy publikasies was die klassis uiteindelik genoodsaak om die saak "... in haar geheel ..." (GKN, 1925) na die sinode te verwys.

\section{Aksies van dr. Geelkerken}

Die volgende aksies luet dieper beslag aan sy beeld as kontroversis gegee 


\subsection{Sy brosjures}

Intussen het dr. Geelkerken by wyse van publikasies die kontroverse buite die baan van die kerklike hantering gevoer. Sy antwoorde aan die klassis, en uiteindelik aan die sinode, het hy in die vorn van brosjures gepubliseer. Hierdie geskrifte het gewoonlik gelyktydig (soms selfs vóór) die indiening van sy antwoorde by die meerdere vergaderings verskyn Veral die voorwoord van dié publikasies was belangrik omdat sy houding teenoor die kerk daarin weerspieël word.

Die publikasie van sy eerste brosjure motiveer hy deur die oortuiging uit te spreek dat die tyd onherroeplik verby is “... dat kerklijke processen zich verborgen afspeelden in de besloten duistenis van geheimzimnige, onderaardsche gewelven. Zij moeten in elk opzicht het licht kunnen velen ..." (Geelkerken, 1925(a):Voorwoord). Ook in die voorwoord tot sy tweede brosjure mak hy smalende opmerkings oor geheimhouding in die "binnekamers" van die "besloten kring der Classicale vergadering" wat hy as "machthebbers" bestempel teen wie hy die stryd tot die einde wil voer (Geelkerken, 1925(b):3,4). In sy derde brosjure skryf hy van die dwang wat hom opgelê is om die bose sweer in die boesem van die kerk oop te steek (Geelkerken, 1925(d):3).

\subsection{Woord en Geest}

Op 2 Oktober, 'n dag nadat dr. Geelkerken sy voorwoord tot die eerste druk van sy derde brosjure geskryf het, en die verskuiwing van die kontrovers van klassisna sinodalevlak dit in die brandpunt laat kom het, verskyn Woord en Geest: (jereformeerd W'eckhlad met dr. Geelkerken as hoofredakteur (Geelkerken, 1925 (c):1). Soos wat dr. Geelkerken die bose sweer in die kerk wou oopsteek, so wou die uitgewers van die blad (Bosch \& Keuning, 1925:1) “... het verkeerde en onwaarachtige ..." in die Gereformeerde Kerke “... uitbannen ...". Hierdie blad kan as 'n spanpoging van die 'jongeren' gesien word om 'n aksie teen die Gereformeerde Kerke onder leiding van dr. Geelkerken van stapel te stuur Hoewel dr. Geelkerken (1925(c).1) in sy inleidingsartikel tell sterkste ontken dat die verskyning van die blad in verband met die "Kwestie-Geelkerken" staan, is die teendeel hiervan bewys met sy felle kritiek teen die Sinode van Assen in die verdere uitgawes. Uiteindelik is die blad teen die sinodebesluit van Assen ingespan "... om te getuigen van onzen geest tegen den geest van Assen ..." (Theyse, 1926: 224).

\subsection{Strategie ter voorbereiding vir die sinode}

In die fase tussen die laaste klassisvergadering en die sinode was dr Geelkerken duidelik daarop uit om stemming ten gunste van sy saak te probeer maak. Hierdie aksie het hy op tweërlei wyse van stapel gestuur 


\subsubsection{Verdere brosjures}

Eerstens het hy sy saak in twee verdere brosjures gestel.

In "Op weg naar de synode" gee hy te kemne dat daar niks agter die hele betrokke kwessie sit nie. Hy aanvaar "... al het geen in de H. Selırift, ook in Genesis 1-3, letterlijk staat, als absoluut gezag hebbende Openbaring God ..." (Geelkerken, 1926(a):44). Terselfdertyd gee hy egter te kenne dat hy hom daarteen sal verset dat die tradisionele eksegese amptelik aan hom opgedring sal word as "... de eenige mogelijke en uitsluitend ware ..." (Geelkerken, 1926(a):44).

Die saak waarom dit vir hom gaan, is of die vryheid van eksegese en voortgaande wetenskaplike ondersoek in die kerk gelhandliaaf sal word (Gcelkerken, 1926(a): 45). Hy stel voor dat die "... suspectverklaring ..." (Geelkerken, 1926(a):45) opgeskort moet word en dat daar op wetenskaplik-teologiese vlak ondersoek gedoen moet word na die vraagstukke wat uit die geding na vore gekom het. Laasgenoemde is gelykluidend met sy voorwaarde vir die ondertekening van die verklaring wat die sinode uiteindelik aan hom voorgelê het (GKN, 1926(b): $123,124)$. Dié voorwaarde is in ooreenstemming met die versock van die 'jongeren' aan die Sinode van Assen on die heersende vraagstukke tc ondersoek $(G K N, 1926(b): 126)$. Dit gee rede on dr. Geelkerken se voorwaarde te sien as die kulminasiepunt van 'n doelbewuste aanslag vanuit die grondliggende stroom van die 'jongeren', naamlik om eksegese onderhewig aan die resultate van die wetenskap te stel. Met die tersydestelling van Assen se uitspraak by die Sinode van Lunteren/Annsterdam 1967/68 het juis hierdie uitgangspunt geseëvier (GKN, 1967/68(b):251).

In "Om het recht van mijn ambt" stel hy die voortgaande ondersoek voor as 'n "... inquisitie ..." (Geelkerken, 1926(b):33) wat teen hom ontketen is.

\subsubsection{Die "Comité-Geelkerken"}

Geelkerken is ook deur "het Comite van tien", oftewel die "Comité-Geelkerken", bygestaan in die bevordering van sy saak $K$. van den Berg, 'n lidmaat van die Gereformeerde Kerk Amsterdam-Suid, het namens dié komitee sy publikasie "Toelichting omtrent de Kwestie-Geelkerken" teen November 1925 laat verskyn. Daarin stel hy die saak voor as 'n blote aksie van 'n groepie "malcontenten" uit die gemeente wie se griewe uit vroeere frustasies spruit (Van den Berg, 1925:4, $6,9,10)$. Verder het dr. A. de Froe, nog 'n lid van die komitee, 'n brosjure "Wilt gijlieden toezien?" gepubliseer waarin liy (soos aangehaal deur De Moor in De Heraut van 29 Nov. 1925) inense aanspoor “... on op de lijsten van het ComitéGeelkerken te teekenen ...". Volgens De Moor was die gerug dat dr. Geclkerken deur die algemene sinode “... 'eruit gewerkt zal worden' ... dic beweegrede agter dié lyste. Hierdie aantyging spruit voort uit 'n uitlating van ouderling 11 Bomas op die klassisvergadering van I April 1925. Op die klassisvergadering van 
13 Oktober 1925 is groot prominensie aan dié uitlating verleen (GKN, 1925:61, 62). Die "Comité-Geelkerken" het dit kennelik aangegryp on dr. Geelkerken as 'n martelaarsfiguur voor te hou en sodoende steun vir sy saak te werf. 'n Skrywer wat onder die skuilnaam "Silvanus" skryf, stel dr. Geelkerken in sy brosjure "De Wondeplek" voor as 'n martelaar wat in die voetspoor van Jesus op pad na die kruis is (Silvanus, 1925:5,6).

Die "Centraal Comité van advies en leidng", wat ná die uitspraak van die Sinode van Assen gestig is, is op die lees van die "Comite-Geelkerken" geskoei met as taak: "... te getuigen van onze geest tegen den geest van Assen ..." (Theyse, 1926:224). Hierdie aksie het untgeloop op kerkskeuring en die stigting van die Gereformeerde Kerken in Hersteld Verband (Geelkerken, 1926(d):49).

\subsection{Aksies parallel met die stryduraag}

Die volgende twee insidente het bygedra tot 'n verdere lading van die spanningsvolle atmosfeer van die belangrikste kerklike geding. Besware hieroor het uiteindelik saam met die beswar oor sy preek op die Smode van Assen gedien.

\subsubsection{Querido se "Saul en Dawid"}

In die week van 13-19 April 1924, kon nadat die klag oor sy preek gelê is, is die toneelstuk van ()uerido, "Saul en Dawid", deur 'n geselskap van Christenstudente in die stadskouburg van Ansterdam opgevoer. Dit het in onderskeidelik De Reformathe ell die Oiveroomsche Kirkhode' aanleiding gee tot 'n hewige polemiek tussen prof. V. Ilepp en dr Geelkerken oor die wenslikheid al dan nie van die inhoud van die toneelstuk. Veral die laaste artikel van dr. Geelkerken het ernstige beswaar van die broeders 11 Kremer en H. van der Schaar van AmsterdamSuid ontlok. In die artikel sknf dr Cieclkerken:

W'ij kunnen ons dus geheel vereengen met de meening van verschillende kanten geut. dal dit stuk doodonskuldig is en zijn mhoud geen bezwaar oplevert ... Zelfs stellen wij er prijs op, nadrukkelijk te verklaren, dat de uitbeelding welke Querido in dit hoogstaande stuk geeft van de personen. zoowel van Dawid als van Saul. ons deze bijbelsclie figuren bijzonder werkelijkt en levend heeft gemaaht in de periode hunnen geschiedenis. waarmede dit treurspel zich bezig houdt. en dat de lezing san zijn stuk ons niet alleen kunstgenot, maar zelfs stichting heeft gegeven. (GKN. 1926(b): 57.)

Hlierteenoor liet die dogmatiese kommissie van die Sinode van Assen (GKN, 1926(b):57) later geoordecl:

dat de David. in Querido's stuk geteekend. niet is de David der Schrift. En het is haas onbegrijplijk. hoe dr Geelkerken kan verklaren. dat de lezing van dit stuk. waaruit een gansch andere geest spreckt dan die der Schrift en dat onderscheidene passages besat. die uit zedelijke ongpunt verte san 
onbedenkelijk zijn te achten, hem stichting heeft gegeven. Uwe commissie meent dan ook, dat dr. Geelkerken's gunstige beoordeling van dit treurspel afbreuk moet doen aan den eerbied voor Gods Woord.

\subsubsection{Die resensie van dr. Oberman se boek}

Op 14 Desember 1924, ongeveer agt maande na die aanlıangigmaking van die klag oor sy preek, het dr. Geelkerken in die Overtoomsche Kerkbode 'n resensie oor 'n boek van dr. Oberman, 'n etiese predikant geplaas. Dié resensie was in die vorm van 'n huldiging van sowel die pas oorlye predikant as sy boek wat, volgens dr. Geelkerken, die hart van menige jongmens brandende gemaak het. Dié uitdrukking was in ooreenstemming met die titel van die boek "Was ons hart niet brandende in ons?". Dr. Geelkerken het die oortuiging uitgespreek dat elkeen wat die boek aandagtig lees, Christus daarin sou sien (GKN, 1926(b):54, 55). Hieroor het 'n klag van E. van Beek, 'n lidmaat van Amsterdam-Suid, by die Sinode van Assen gedien. Sy beswaar was dat die Christus wat in die boek verkondig word, nie die Christus van die Skrif is nie (GKN, 1926(b):55). Die dogmatiese kommissie van die sinode het geoordeel dat daar begrip is vir die feit dat $\mathrm{dr}$. Oberman 'n vriend van dr. Geelkerken was, maar dat hy gefouteer het in soverre hy nie ook teen die dwalinge in die boek gewaarsku het nie (GKN, 1926(b):57).

Die feit dat dr. Geelkerken daarvan bewus was dat hy onder verdenking van etiese neigings gestaan het (Hendrikse \& Haan, 1925:30) en 'n klag van leerstellige aard reeds teen hom aanhangig gemaak is, het 'n uitdagende karakter aan sy optrede gegee.

\section{Dr. Geelkerken en die Sinode van Assen}

In die ondersoek na die regsinnigheid van dr. Geelkerken het die dogmatiese kommissie van die sinode negentien vrae aan hom gestel. Van die negentien vrae het drie oor die bykomstige sake gehandel waarna hierbo verwys is. Die ander sestien was toegespits op die skriftelike weergawe van sy preek.

Die styl waarin dr. Geelkerken die kommissie van antwoorde bedien het, was heeltemal in stryd met die gees van die ondertekeningsformulier (Kruger, 1991: 192). Op ' $n$ hooghartige wyse het hy, met sy antwoorde in die vorm van 'n referaat geklee, die kommissie 'n lesing in Skrifbeskouing gegee (Kruger, 1991:193). In die voorwoord tot sy brosjure "Mijn antwoord aan de Synode Mechanische binding of organisclse vrijheid inzake Sclriftbeschouwing", waarin hy sy antwoorde 'n week vóó die oorhandiging aan die dogmatiese kommissie gepubliseer het, dig hy die meganiese Skrifbeskouing aan die sinode toe en eis die organiese Skrifbeskouing vir homself op (Geelkerken, 1926(c):6). Sy nadere bepaling van die siening van die kerk, “... die zich gemakkelijk mnakt door zicl 'aan de letter 
der Schrift vast te klampen' ..." (GKN, 1926(b):2l), is duidelik teen die kerk se letterlike opvatting van die sogenaamde vier besonderhede gemik.

Die ontwykende en kritiese aard vall sy antwoorde het dit onmoontlik gemaak on te bepaal of hy die vier besonderliede as historiese werklikheid al dan nie venolk. Waaroor hy wel baie duidelik was, is die feit dat hy nie die tradisionele siening as die enigste moontlikheid aanvaar nie (GKN, 1926(b):29). Dié oortuiging grond hy op "... die betrouwbare resultaten van de nieuwere natuur- en geschiedwetenschap ..." (GKN, 1926(b):29). Omdat dr. Geelkerken in gebreke gebly het on van sodanige ander opvatting, wat nie in stryd met die Skrif sou blyk te wees nie, rekenskap te gee, was die sinode genoodsaak om 'n uitspraak te maak waarin die sinode sy siening van die listoriese werkliklueid oor die vier sogenaamde besonderhede eksplisiet gestel het. Van dr. Geelkerken is verlang om 'n verklaring te onderteken wat hom in sy opvatting van Genesis 2 en 3, en sy leer daaroor, sonder voorhehond sou bind aan die uitspraak wat die sinode aangaande die opvatting oor dié Skrifgedeclte gelewer het (GKN, 1926(a):53). Die bepaling "sonder voorbehoud" moet gesien word in die lig van dr. Geelkerken se strategie om deurgaans die waarde van 'n positiewe verklaring met 'n voorbehoud te neutraliseer (GKN, 1926(c): 121). Weer het die voorbeloud nie uitgebly nie: hy sou die verklaring onderteken mits die sinode sy uitspraak aangaande Genesis 2 en 3 sou onderwerp aan "... de wettige vryleid van beoordeling door een wetenschap, die zich gebonden houden aan Gods woord ..." (GKN, 1926(a):76) - 'n beoordeling wat so spoedig moontlik na afloop van die sinode moes geskied (GKN, 1926 (b): 124).

Die sinode het die voorbehoud van $d r$. Geelkerken geinterpreteer as 'n weiering on die verklaring te onderteken, daarom is daar oorgegaan tot sy skorsing, en uiteindelik sy afsetting (GKN, 1926 (b) 129; GKN, 1926(a).91). Op sy afsetting het dr. Geelkerken, met behulp van die "Centraal Comite van advies en leiding " en deur middel van sy lyfblad Woord en (jeest, gereageer met 'n aksie teen “... den geest van Assen ..." (Theyse, 1926:224) en die uiteindelike stigting van die Gereformeerde Kerken in Hersteld Verband (Geelkerken, 1926(d):49).

\section{3. 'n Evaluering van dr. Geelkerken se optrede}

Benewens die feit dat dr. Geelkerken in kontroversistiese aanleg gehad het, is sy optrede ook deurgaans deur kontroversisme gekenmerk. Dit wil voorkom asof laasgenoemde opsetlik was

\subsection{Die doel van sy optrede}

Sedert die Sinode van l.eeuwarden in 1920 was dr. Geelkerken deurgaans met die kerk in botsing. Die grondliggende oorsaak was sy vereenselwiging met die ideaal van die 'jongeren' om antwoorde te soek op die vraagstukke van die tyd (Wielenga, 1920(b):79). Hulle was in reaksie teen, soos hulle dit gesien het, die 
selftevredenheid van die kerk na die Doleansietyd (Wielenga, 1921:173; Dijk, 1921:125). Hulle was daarvan oortuig dat veral die nuwe kennis wat opgrawings oor die kultuur-historiese agtergrond van die Bybel aan die lig gebring het, ' $n$ nuwe besinning oor die verklaring van die Skrif noodsaaklik gemaak het (GKN, 1926(b):120). Op die Sinode van Leeuwarden is ds. Netelenbos juis afgesit oor sy siening ten opsigte van die vorn van inkleding van Genesis 2 en 3 (GKN, 1920:117, 119).

Die ontwykende houding van dr. Geelkerken gedurende die geding skep egter die indruk dat hy hom nie, soos ds. Netelenbos, aan veroordeling deur die sinode wou blootstel nie. Kuiper (1972:350) sien dit so dat dr. Geelkerken nie die foute van ds. Netelenbos wou herhaal nie. Tegelykertyd wou hy die saak van die 'jongeren' se wetenskapsideaal dien. Dit blyk uit die feit dat hy die kerklike ondersoek altyd probeer dwing het in die rigting van sy cie doelwit, naanlik herbesinning oor die beskouing van die Skrif. Die steun wat hy in dié verband van die 'jongeren' geniet het, blyk uit hulle versoekskrif aan die sinode insake herbesinning oor die beskouing van die Skrif (GKN, 1926(b): 120, 121, 127, 128).

\subsection{Die gevolge van dr. Geelkerken se optrede}

Dr. Geelkerken se kontroversistiese optrede was tot nadeel van sowel die ideaal van die 'jongeren' as die heil van die kerk. In die eerste plek het dit tot kerkskeuring gelei. Tweedens, en baie ironies, het juis die beweging van die 'jongeren' en hulle saak baie skade gely. Die besluit van die Sinode van Lecuwarden om die belydenisskrifte te hersien en die hemuwing van die liturgie te oorweeg, het alles in die teken van vemuwing gestaan - ooreenkomstig die ideaal van die 'jongeren'. Tog het dit alles doodgeloop by die Sinode van Anllem 1930 (GKN, 1930:40) en dit vanweè 'n reaksie teen die Geelkerken-kontroverse (GKN, 1930:8). Geelhoed (1950:20) spreek diè mening uit: "De beweging der "Jongeren' verzandde langzamerliand. Vooral na het conflict Geelkerken." Derdens was sy optrede direk verantwoordelik vir die ontsporing van die kerkregtelike hantering van die kontroverse; eers op klassis- en uiteindelik op sinodale vlak. Vierdens het die ontwykende aard van dr. Geelkerken se antwoorde en sy gelyktydige oophou van die moontlikheid van 'n ander as die tradisionele siening ten opsigte van Genesis 2 en 3 (GKN, 1926(a):53), die sinode genoodsaak on 'n uitspraak te lewer waaraan hulle dr. Geelkerken wou bind ten einde die gevaar van willekeurige Skrifuitleg te voorkom. Dié omstandigheidsfaktor het aan die uitspraak 'n afgrensende karakter gegee en die gevolglike kritiek van cksklusiwiten (GKN, 1967/68(a): 156) op die hals gehaal. Aanvullend hiertoe het sekere elemente in die bewoording soos die "klaarblyklike bedoeling van die Skrif" en die "sonder voorbehoud" wat as eis vir ondertekening aan dr. Geelkerken gestel is, by kritici die indruk geskep asof die sinode op 'n aantnatigende wyse dieselfde gesag as dié van die Skrif vir sy uitspraak wou opeis (GKN, 1926 (c):114, Buskes, 1974:20). Dit, asook die manier waarop die saak kerkregtelik gehanteer 
is, het tot felle kritiek teen die sogenaande "gees van Assen" gelei en het uiteindelik die tersydestelling van die uitspraak (GKN, 1967/68(a):156) tot gevolg gehad. Deur die tersydestelling is aan die Skrifbeskoulike waarde van die uitspraak van Assen 1926, wat deur Schelhaas (1968:90) as “... een toetsteen voor de zuiverheid der leer ..." gehuldig word, afbreuk gedoen en is die “... uitsonderingsposisie van die Reformatoriese Skrifbeskouing ..." (Duvenage, 1967:3) tot nog 'n kleiner kring in Gerefonneerde geledere beperk.

\section{Bibliografie}

BOSCH \& KEUNING; 1925 Van de Uitgewers Word en (ieest, 1(1):1, October 2

BUSKES, J J 1961 Johannes Gerardus Geelkerken (Alkmaar, 13 Junie 1878 - Amsterdam, 3 Februarie 1960) (l'n Jaarboek van de Maatschappij der Nederlandsche Letterkunde te Leiden Leiden : E J Brill $p$ 52-56)

BUSKES, J J 1974 Droon en protest getuigenissen uit een halve eeu van strijd Baam Ten Have

DE MOOR, JC 1925 In en on de Gereformeerde Kerken De Herail. Nov 29 (Sonder bladsynommers )

DIJK, K 1921 De critiek der ouderen II De Reformatie, I(17) 125, Jan 21

DUVENAGE, S.C IV 1967 Die gesag van die Heilige Skrif Inougurele rede Potchefstroom PU vir CHO

EENE GEREFORMEERDE, 1921 Een "Jonge" stem Je Reformasic, 1(25) 189, Maan 18

GEELHOED, J 1950 "De reformatie" en de Jongeren De Reformatie, 26(1):19, Oct 7

GEELKERKEN, J G 1909. De empirische godsdienstpsychologie Amsterdam : Scheltema en Holkema's Boekhandel

GEELKERKEN, JG 1925(a) Vragen mij voorgelegd door de Classis Amsterdam der Gereformeerde Kerken, en mijn antwoord daarop Amsterdam N V Boekhandel Ten Have

GEELKERKEN, J G 1925(b) Oude vragen en een nieuwe antwoord De Classis den Gereformeerden Kerken nogmaals te woord gestaan Amsterdam N V Boekhandel Ten Have

GEELKERKEN, J G 1925(c) Inleidend Woord Hixul en (ieest, 1(1) 1, Oct 2

GEELKERKEN, J G 1925(d) Nadere mededeelingen inzake mijn kerklijke geding Amsterdam N V Boekhandel Ten Have

GEELKERKEN, JG 1926(a) Op wey naar den synode Amsterdam N V' Boekhandel Ten Have

GEELKERKEN, J G 1926(b) Om het recht van mijn ambt Amsterdam N V Boekhandel W Ten Have

GEEI.KERKEN. J ( 1926 (c) Mijn antwoord aan de synode: Mechanische binding of organische vrijheid inzake Schriftbeschouning Amsterdam N V Boekhandel W Ten Have

GEELKERKEN, J G 1926(d) De beginselverklaring der kerklijke Conferentie, 11-13 Oct 1926 te Amsterdam Hoxd en (iees, 2(7) 49, 50, Nov 12, 2(8) 57, 58, Nov 19, 2(9):65, 66, Nov 26, 2(10) 73, 74, Dec 3

GKN Afkorting vir Gereformeerde Kerken in Nederland

GKN 1920 Acta der Generale Synode van de Gereformeerde Kerken in Nederland gehouden te Leeuwarden van 24 Augustus - September 1920 Kampen Kok

GKN 1925 Memorie der Classis Amsterdam van de Gereformeerde Kerken in Nederland (In GKN 1926 Memorie-boek behorende bij de Acta den Buitengewone Generale Synode van de Gereformeerde Kerken in Nederland Kampen Kok p 1-66)

GKN 1926(a) Acta der Buitengewone Generale Synode van de Gereformeerde Kerken in Nederland Kampen Kok 
GKN 1926(b). Bijlagen bij de Acta van den Generale Synode van de Gereformeerde Kerken in Nederland. Kampen : Kok. (In GKN 1926(a) Acta der Generale Synode van de Gereformeerde Kerken in Nederland. Kampen : Kok p 1-133.)

GKN 1926(c). Bijlagen bij de Acta der voortgesette Buitengewone Generale Synode van de Gereformeerde Kerken in Nederland Kampen : Kok (In GKN 1926(d) Acta der voortgezette Buitengewone Generale Synode van de Gereformeerde Kerken in Nederland Kampen : Kok p 1-167.)

GKN 1930. Acta der Generale Synode van de Gereformeerde Kerken in Nederland Kampen : Kok

GKN 1967/68(a) Acta van de Generale Synode van Amsterdam 1967 en 1968 van de Gereformeerde Kerken in Nederland. Kampen : Kok

GKN 1967/68(b) Bijlagen bij de Acta van de Generale Synode van de Gereformeerde Kerken in Nederland Kampen: Kok

HENDRIKSE, A \& HAAN, T. H. 1925. Ingesonden stukken Woxul en (icest, 1(4) 30, Nov 13

KNOPPERS, B A 1926. Pilaar en vastigheid der waarheid Een woord naar aanleiding van de zaak - Dr. J.G Geelkerken. Amsterdam Drukkerij Holland

KRUGER, G.L. 1991. Die kontroverse tussen dr J G Geelkerken en die Gerefonneerde Kerke in Nederland 23 Maart 1924 - 17 Maar 1926 Potchefstroom : PU vir CHO (ThMVerhandeling)

KUIPER, D Th 1972. De voormannen Een sociaal-wetenschappelijke studie over ideologie, konflikt en kerkgroepvorming binnen de Gereformeerde wereld in Nederland tussen 1820 en 1930. Kampen Kok

KUYPER, H H. 1925. Dringende nood De Hercull, 2494, Nov 8 (Sonder bladsynommers )

MEULEMAN, GE 1956 Herman Bavinck (In Christelijke Encyclopedie, I Kampen: Kok p. 487-490)

MARINUS, H 1925 Het oordeel zuiver' Mijn bezwaren tegen de preek over Zondag 3 Eenige pleitreden den Geelkerken-groep, en iets aangaande de malcontentie in Amsterdam-Zuid aan Gereformeerd Nederland voorgehouden ( $I \prime \prime$ V Van den Berg, $\mathrm{K}$ Toelichting omtrent De Kwestie-Geelkerken Amsterdam W Ten Have p 1-31)

MONNIK, J H. 1920 Wat verdeeld en wat samenbindt: de stryd tusschen Prof. Ridderbos en Dr Geelkerken nader bezien Amsterdam Ten Have

RIDDERBOS, J 1920 Kerk en wêreld Dr Geelkerken's aanval op de Generale Synode afgewezen Kampen Kok

SCHELHAAS, J (Hzn) 1968 De val van Assen Vlaardingen : Uitgeverij Holland

SILVANUS 1925 "De Wondeplek". Dingen die gezegd moeten worden in het kerkelijk gedrag tegen Dr J G Geelkerken Amsterdam Systema (/n Van den Berg, K Toelichting omtrent De Kwestie-Geelkerken Amsterdam W Ten Have p 1-16)

THEYSE, F.JD 1926. Centraal Comite van Advies en leiding W'(x)rd en (jeesw. 1(29) 224, Mei 7.

VAN DEN BERG, K 1925 Toelichting omtrent de Kwestie-Geelkerken Amsterdam N V Boekhandel $W$ Ten Have

VAN DEN BRINK, HC 1925 Kerkelijk leven W(x)rden (jeest, 1(6) 42,43,44, Nov 27

VAN RHIJN, M 1920 Taak en arbeid der Nederlandsche Christen-Studenten Vereeniging Utrecht : GJ A Ruys

WIELENGA, B 1920(a) De Beweging der 'jongeren' IV Ite Reformalle, 1(10) 71,72, Dec 3

WIELINGA, B 1920(b). De Beweging der 'jongeren' V De Refornatle, I(11) 79, Dec 10

WIELENGA, B 1921 Het doel der 'jongeren'. IV Ie Reformatie, 1(23) 173, 174, Maan 4 